Гриневич А. А. О структурной организаџии обрядовых песен медвежьего праздника казымских хантов...

УДК $394.2+394.268 .7+398.88(=511.142)$

DOI 10.25205/2312-6337-2019-1-46-52

\title{
А. А. Гриневич
}

Институт филологии СО РАН

\section{О структурной организации обрядовых песен медвежьего праздника казымских хантов: песни богов удачи миш ар и песни-молитвы пойәкты ар}

Статья посвящена описанию принципов сюжетостроения обрядовых песен медвежьего праздника у казымских хантов. Обрядовым песням медвежьего праздника свойственна многоуровневая структурированность текста. В поле зрения автора попадают десять песен жанра миш ар и семь песенмолитв (пойәкты ар). Сравнение песен этих жанров позволило выделить две основные разновидности: мужские и женские. Им свойственны следующие константные элементы в структуре повествования: зачин, описание дома божества, выход на улицу, получение вести от ворона, сборы в дорогу, приход божества на медвежий праздник, исполнение танца, приносящего удачу. Песни жанра миш ар и пойәкты ар типизированы в разной степени. Божества мужского пола и женского в песнях миш обладают большим числом общих черт. Великие божества, которым посвящены песни-молитвы, в большей степени индивидуальны.

Ключевые слова: обрядовый фольклор, типическое место, типизированное сюжетостроение.

Обрядовые песни медвежьего праздника хантов, в силу своей сакральности и большого объема, имеют довольно жестко организованную структуру. Типизированными в них являются не только формулы, из которых они состоят [Гриневич, 2016], но и сюжеты [Гриневич, 2018]. В статье речь пойдет о типических сюжетах песен жанров миш ар и песен-молитв (пойәкты ар), исполняемых во время медвежьего праздника северных (казымских) хантов. Для обозначения устойчивых повторяющихся сюжетов был выбран термин «типическое место» [Кузьмина, 2006], так как обрядовые медвежьи песни структурно близки эпической сибирской традиции. Под структурой обрядовых песен мы будем понимать последовательность эпизодов: типических мест или мотивов, которые состоят из более или менее устойчивой последовательности формул, объединенных общей темой.

Материалом для статьи послужили обрядовые медвежьи песни на казымском диалекте хантыйского языка, записанные в д. Казым в 2002 г. в ходе комплексной фольклорной экспедиции сотрудниками сектора фольклора народов Сибири ИФЛ СО РАН. Исполнителями на празднике были Петр Иванович Сенгепов, Семен Егорович Тарлин, а также Алексей Васильевич Молданов, Тимофей Алексеевич Молданов, Сегей Васильевич Кечимов.

Материалом для статьи послужили десять песен жанра миш ар. Буквальный перевод названия этого жанра - 'песня удачи' или 'песня [богов, приносящих] удачу'. Божество входит, чтобы подарить людям свой танец, приносящий благо человеку. Песни исполняются от лица божества исполнителем, одетым в соответствующий костюм. Исполнитель роли богини миш входит с лицом, закрытым платком, исполнитель роли бога-мужчины закрывает лицо берестяной маской. Все они приходят на праздник с посохом. Посох, который в данном контексте символизирует стрелы, - картәу њол, букв.

Гриневич Анна Александровна - кандидат филологических наук, научный сотрудник сектора фольклора народов Сибири Института филологии СО РАН.

Контактная информация: ул. Николаева, д. 8, к. 205, г. Новосибирск, 630090, Российская Федерация.

E-mail: annazor@mail.ru ; тел./факс (раб.): 8-(383)-330-14-52.

ISSN 2312-6337. Языки и фольклор коренных народов Сибири. 2019. № 1 (37). С. 46-52.

(C) А. А. Гриневич, 2019. 
'железная стрела' - это символ власти, причастности к божественному, способности творить [Молданов]. Некоторые божества, например, Калтащ (Кӑлтащ), 'Многих домов женщина' (Ар хотәу ими), а также хозяин рыб Хоймас приходят на праздник сразу с двумя посохами. Их песни исполняются под аккомпанемент, создаваемый постукиванием одной «стрелы» о другую. Внутри жанра песен мищ существуют разновидности, которые зависят от содержания. Так, частным видом миш ар можно считать тыли ар - 'песню печали'. К этой разновидности относится, например, песня «Кунават миш нэ ap» - «Песня богини с [реки] Кунават» (текст № $4^{1}$ ), в которой рассказывается, как богиню против воли выдали замуж.

Образы божеств обладают как общими, так и уникальными чертами, присущими только им одним. Сравнение десяти песен жанра миш ар позволило выделить типизированный портрет божеств мужского пола и женского. К женским разновидностям песен жанра миш ар относятся следующие шесть песен: «Касәм ими мойлаты йӑуты ар» - «Песня Казымской богини о поездке в гости» (текст № 1), «Ай Јэв тый миш нэ ар» - «Песня богини притока малой Сосьвы» (текст № 2), «Јэв кутәп миши най ар» - «Песня богини середины Сосьвы» (текст № 3), «Кунават миш нэ ар» - «Песня богини с [реки] Кунават» (текст № 4), «Йємәу Ас муви миш нэ ар» - «Песня богини Священной Оби» (текст № 5), «Поләм йухан миш нэ ар» - «Песня богини с реки Пелым» (текст № 6). Эти песни исполняются во второй день праздника, в части, посвященной женщинам. Исполнители, шутя, говорят, что настало время женщин, теперь они всем распоряжаются.

К типическим местам женских песен миш ар относится в первую очередь зачин ${ }^{2}$. Например: Малаә найлаә анкиөилә, малаә найлаә эвиөийэлә 'Я богиня-мать, я богиня-дочь' (текст № 2, стк. 2, 3). Это вступление сразу характеризует вошедшую как богиню.

Далее называются земли, в которых живет богиня, описывается ее дом. Пример из текста № 6, стк. 89-98:

Йувра йинкәп лантәуа Поләм,

Тыйдуа Поләм тыйал хущии,

Тор курр пөрмәм кӑтла Поләм

\section{Кўтэмә хущии}

Альен сўмтап сэвла йӑм вөрт,

Акием хущи,

Ма, най, омсыйөләмем ищи,

Хуш йўх сөхтәм йӑм хот,

Јыпена хоты лыпема хущи,

Най, ма, омсылумем ищи.
На извилистых водах кормящего Пелыма,

В верховьях Пелыма с верховьями,

Между двух Пелымов, журавлиными ногами истоптанных,

Там,

Среди крепких берёз у славного ворта с косами,

У дяди, там,

Я, богиня, сижу тоже,

В славном доме, из крепких деревьев построенном,

Внутри дома с внутренностью, там,

Богиня, я, сижу тоже.

Описание местности, о которой поется после, является уникальным для каждой песни.

Следующее типическое место характеризует каждую из богинь как рукодельницу: Йинтәпәл / Лўйәл ${ }^{3}$ карты катлыијәмә 'Железную иглу / наперсток держащая' (текст № 1, стк. 20, 21, 24, 135, $136,171,173,231,232,238,247)$. В этой части могут называться даже некоторые орнаментальные мотивы, описывается работа швеи. Устав от шитья, богиня выходит на улицу, чтобы размяться. Пример из текста № 3, стк. 34-37:
Пасумал куирийө олуэмә ям йирә
Одеревеневшие кончики славных ног
Тунмататыйе
Размять
Кимпен хотыйе кимпиема
Наружу дома с наружностью
Ма, найә, єтьлийөлатэмә ищийө.
Я, богиня, выхожу тоже.

Богиня прибирает шитье и выходит. Довольно подробно описывается выход из дома, открывание двери. Дверь как переходное пространство между внутренней частью дома и наружной имеет важное значение.

На улице богиня прислушивается к тому, что происходит в дальних землях. Затем прилетает ворон, который приносит весть о медвежьих игрищах. Прежде чем отправиться в дорогу, богиня должна получить разрешение. Пример из текста № 5, стк. 86-89:

Айэм төхийө йӑми олауд

О вестях из славных пределов

\footnotetext{
${ }^{1}$ Номер в скобках соответствует номеру источника, список которых приведен в конце статьи

2 Для удобства мы будем выделять названия типических мест жирным шрифтом.

3 Луй - букв. 'палец'.
} 
Гриневич А. А. О структурной организаџии обрядовых песен медвежьего праздника казымских хантов...

Йинкјаә вөрт пухә сэвау вөн вөрт,

Ащем пијаә

Ма паә лупийөләмем ищийө.
С великим господином с косами, водяного господина сыном,

Вместе с отцом

Я еще говорила тоже.

Получив разрешение, богиня собирается в дорогу: Лємтәма / Пунәма найийө тэлэмә олауә 'В одежды одевающаяся / Облачающаяся богиня’ (текст № 4, стк. 153-154). На праздник богиня либо приходит сама: Вөнтэн лөңхийө хар сөхәм 'Широким шагом лесной богини' (текст № 5, стк. 128), либо ее доставляет божество в облике птицы. Пример из текста № 4, стк. 158-161:
Јайла хөлахә акиөемәнә
Тухлаә поухәл йөхәлә кута
Алмиләмајә вушийөеныйө,
Лув паә төтьлиөламајә ищийө.
Черный дядя ворон,
На место между крыльями, [похожее] на лук,
Туда [ее] поднял,
Он еще понес [еe] тоже.

Богиня входит в дом, где проходят игрища. Момент входа (перехода из одного пространства в другое) снова акцентируется. Далее дается эпитет дому, где проходит праздник; говорится о цели визита: станцевать танец лесного, таежного божества; предлагается умеющему играть на музыкальных инструментах человеку поиграть, чтобы богиня могла исполнить свой танец. После чего исполнитель роли богини миш танцует три круга и выходит. Этот набор типических мест встречается во всех рассматриваемых песнях женского типа.

К мужским песням жанра миш относятся четыре песни: «Сөрәм ики»- «Господин [реки] Сорум» (текст № 7), «Хөрәу ики» - «Господин Херэн» (текст № 8), «Вєри вошәу ики миши ар» - «Песня удачи покровителя городка Вэри» (текст № 9), «Мосәм ики ләсау лев» - «Песня слуги покровителя Назыма» (текст № 10).

Песни божеств мужского пола строятся в целом по той же схеме, что и женские. Лишь некоторые части в них освещены более подробно.

Песня начинается с обращения к гостям. Эта часть достаточно краткая, но устойчивая. Называется место, куда пришло божество: Њөрәм войә омсәма кашәуа хотайө 'В веселый дом сидящего тундрового зверя' (текст № 9, стк. 2-3, 142-143), то есть в дом, где проходят медвежьи игрища. Иносказательно говорится, что вошло божество, поскольку места, откуда оно пришло, достаточно известны: Нємјы мултыйө тахєм эвалта 'С какого-то неназываемого места, оттуда' (текст № 8, стк. 4). Название местности напрямую не упоминается. О том, какое пришло божество, слушатель узнает в процессе исполнения песни. В этом кроется и некоторая интрига: зрители должны угадать, о ком идет речь. Для людей, выросших в традиции, это не составляет труда. О священных местах, предметах, существах, событиях говорить можно только иносказательно.

Переходом к следующему блоку в сюжете песни служит формула-обращение к зрителям: Мувема / йинкема уши ямийө олан нынә лөйийөлатэмә ищи 'О землях, / Водах в славных пределах вам пропою тоже’ (текст № 9, стк. 6-7).

Типическое место, описывающее территорию, откуда прибыло божество, является центральным в песне. В отличие от женских песен миш в мужских песнях описывается дорога к местам проживания божества. Возможно, это связано с тем, что женщина - существо, привязанное к дому, мужчина же, напротив, более мобилен. Эта часть гораздо более подробная, чем в женских песнях, она может достигать 60-70 поэтических строк. Ориентирами, как и в жизни, служат реки, озера, ручьи. Пример из текста № 7, стк. 33-35:
Вўртәуа йинкпи лантәу Амня
Овәуа йухан овәл пелаә
В красные воды кормящей Амни,
Төтыйе туми йўпиетна...
В сторону устья реки с устьем
После того как поведете...

Далее поется о повседневной деятельности, которую ведет мужчина-бог. Пример из текста № 8 , стк. 73-76:
Ђўкен щолпи щоләу вар
Вертэл тум пурайна,
Ай њӑләк хйл мөхәл щйю
Мөхәла шошиийәлтэлә.
Плотный жердяной запор с жердями
В ту пору ставлю,
Маленьких мальков рыбы в изобилии,
В изобилии вычерпываю.

Характер деятельности зависит от особенностей территорий: рыболовство, охота. Естественно, описываются реалии повседневной жизни, которую ведут люди, живущие на данной территории. Но она подается как деятельность, которую ведет божество-покровитель данных мест. 
Весть о медвежьем празднике так же, как и в песнях богинь, приносит ворон. Разрешение, чтобы отправиться в дорогу, богу-мужчине не нужно.

К типическим местам может быть отнесен эпизод сбора в дорогу, одевание. В этой части исполнитель использует такие же формулы, что и в женских песнях, употребляя только вместо слова най 'богиня' - слова ики 'мужчина' или вөрт 'бог, господин'.

Кольцевая структура песни снова приводит слушателей в дом, где проходят игрища. И божество сообщает о цели своего визита - исполнить танец удачи. Пример из текста № 10, стк. 90-93:

\author{
Вөнтэмә лөухийө мишийө йакєм, \\ Вур калтә вөла мишийө йакем \\ Йакем йактыйө пата, \\ Ма, вөрт, луутыйөлдмєм.
}

\begin{abstract}
Удачу [приносящий] танец лесного божества, Удачу [приносящий] танец таежного божества, Чтобы танец станцевать,

Я, господин, зашел.
\end{abstract}

Каждая такая сценка заканчивается исполнением танца.

Таким образом, песни миш имеют две основные разновидности: исполняющиеся от имени богини най или бога ворта. В них отражается разделение культуры на мужскую и женскую сферы. Так же как и в случае с другой разновидностью обрядовых медвежьих песен кайөәу ар, видов миш ар гораздо больше. Мы описали только типичные сюжетные блоки, которые встретились нам во всех проанализированных песнях этого жанра, естественно, сюжет каждой песни гораздо богаче.

Менее типизированными являются структуры сюжетов песен-молитв - пойәкты ap, которые также называются вөн ар 'великие (большие) песни'. Они исполняются в последнюю ночь, которая считается самой священной, потому что на праздник начинают приходить великие божества, представители высшего пантеона. Их исполнение отделяется от остальных специальными песнями, очищающими помещение, например, «Йєм эвәтты ар» - «Священное перерубающая песня». Все в доме окуривается. Песни исполняются от имени человека, обращающегося к божеству высшего пантеона. Порядок исполнения песен зависит от ранга божества и места проведения игрищ. Первыми исполняются песни тех божеств, которые приходят в черном, продолжается праздник песнями «белых» божеств. Последней исполняется песня $A c$ тый ики, который в настоящее время является самым почитаемым мужским божеством. Такие песни исполняют сразу несколько человек. Один человек поет песню, другой, одетый в одежды, характеризующие божество, исполняет танец, за ним входят также несколько актеров, обозначающие его свиту. Слуги приводят божество, ждут, когда он исполнит свой танец, затем уходят вслед за ним. Один из слуг должен поцарапать исполнителя роли бога по спине, как будто когтями медведя, чтобы «отцарапать» себе удачу [Молданова, 2002, с. 167]. Танцоры используют различный реквизит, например, хвосты животных, снег и др., что зависит от представляемого божества, его характера, мифологии, с ним связанной. Исполнитель размахивает предметами, часто задевая зрителей, таким образом распространяя на них удачу, которую несет этот божественный танец. Исполнитель роли божества Ac тый ики делает танцевальные движения одной рукой (другая спрятана под ритуальным халатом). Считается, что это божество настолько сильно, что, двигая двумя руками в танце, может уничтожить мир. Чтобы сымитировать танец семи божеств, который также исполняет только один человек, используется рама с прикрепленными на нее семью крестиками. Эта рама оборачивается платками, которые хранятся в священном прикладе. В танце исполнитель держит ее над головой, тряся ею в разные стороны. Ранг этих божеств так велик, что не позволяет им касаться земли. По этой же причине перед исполнением песни Ac тый ики кастрюли и другую кухонную утварь в доме переворачивают вверх дном, либо выставляются 4 серебряные блюда, на которые должен встать конь божества.

Песни-молитвы в меньшей степени обладают типическими чертами, потому что обращены к конкретному божеству. В них описываются уникальные отличительные черты божеств, их функции, владения. Все это делает песни жанра пойәкты ар непохожими друг на друга по содержанию. То же мы наблюдали при анализе песен жанра кайөән ар и их менее типизированной разновидности - песен-мифов [Гриневич, 2018].

Типические места выделены на основе анализа вербальных текстов семи песен-молитв: «Јорен хулы сэвпи вөрт» - «Озерной рыбы господин с косами» (текст № 11), «Йєм вош ики» - «Господин священного города» (текст № 12), «Тэк ики» - «Тэгинский господин» (текст № 13), «Јэв кутәп ики» «Господин середины Сосьвы» (текст № 14), «Пашит вөрт» - «Пашит ворт» (текст № 15), «Ай вөрт»»- «Младший ворт» (текст № 16), «Ас тый ики» - «Верховьев Оби господин» (текст № 17).

Типическими являются лишь некоторые эпизоды этих песен. К ним относится описание дома, в котором сидит божество. Божество вөрт сидит с пером в руке и пишет. Пример из текста № 13, стк. 275, 276: 
Гриневич А. А. О структурной организаџии обрядовых песен медвежьего праздника казымских хантов...

Кўрәк тухәл ар ханши

Верт па ханшииәләтәл.
Многие узоры орлиным пером

Ворт еще узорит.

Это характеристика божества высшего пантеона ${ }^{4}$. Эта черта близка, в частности, иранской культуpe, влияние которой также проявилось в русском фольклоре в образе небесной книги [Топоров, 1978, c. 150-154]. О том, что где-то проходят игрища, божество знает без чьей-либо подсказки - он сам творец судеб.

Сборы в дорогу совпадают с аналогичным сюжетным блоком в миш ар. Типической можно считать также концовку, в которой божество исполняет танец. Но если танец божеств миш приносит удачу на охоте, в промыслах, то этот танец более высокого порядка, и его действие распространяется на качество жизни людей в целом. Пример из текста № 15, стк. 26-28:

Эви шаљпи шаљәуа йакен,

Пухен шаљпи шаљәуа йакен

Девочек жалеющий жалостливый танец,

Нау ат йакијәмен ищии.

Мальчиков жалеющий жалостливый танец

Ты да станцуешь тоже.

Таким образом, песни жанров миш ар и пойэкты ар типизированы в разной степени. Если божества мужского и женского пола в песнях миш обладают общими чертами, то великие божества, которым посвящены песни-молитвы, в большей степени индивидуальны.

\section{Список литературы и архивных источников}

Гриневич А. А. Устойчивые элементы поэтической системы обрядовых песен медвежьего праздника казымских хантов: поэтическая формула // Сибирский филологический журнал. 2016. № 4. С. 18 27.

Гриневич А. А. О структурной организации обрядовых песен медвежьего праздника казымских хантов // Сибирский филологический журнал. 2018. № 4. С. 18-27.

Кузьмина Е. Н. О новых аспектах изучения произведений героического эпоса народов Сибири: опыт систематизации «общих мест» // Первый Всероссийский конгресс фольклористов: Сб. докладов. М.: Гос. республ. центр рус. фольклора, 2006. Т. 3. С. 55-69.

Молданов Т. А. Посох, применяемый в медвежьих игрищах: Рукопись // Личный архив А. А. Гриневич.

Молданова T. А. Значения частей тела в сновидениях хантов // Народы Северо-Западной Сибири. Томск: Изд-во Том. гос. ун-та, 2002. Вып. 9. С. 166-171.

Tопоров В. Н. Еще раз об и.-е. *BUDH- (:BHEUDH-). Русская «Голубиная Книга» и иранский Bundahišn. // Этимология. 1976. М., 1978. С. 135-153.

\section{Список источников}

1. Рукопись песни «Касәм ими мойлаты йӑнты ар» - «Песня Казымской богини о поездке в гости». Исполнена П.И. Сенгеповым в 2002 г. в д. Юильск. Запись Г. Е. Солдатовой, Г. Б. Сыченко. Расшифровка, подстрочный перевод - Т. А. Молданов, уточненный перевод - А. А. Гриневич. Аудиозапись и рукопись хранятся в архиве сектора фольклора народов Сибири ИФЛ СО РАН.

2. Рукопись песни «Ай Јэв тый миш нэ ар» - «Песня богиня притока малой Сосьвы». Исполнена С. Е. Тарлиным в 2002 г. в д. Юильск. Запись Г. Е. Солдатовой, Г. Б. Сыченко. Расшифровка, подстрочный перевод - Т. А. Молданов, уточненный перевод - А. А. Гриневич. Аудиозапись и рукопись хранятся в архиве сектора фольклора народов Сибири ИФЛ СО РАН.

3. Рукопись песни «Јэв кутәп миши най ар» - «Песня богини середины Сосьвы». Исполнена С. Е. Тарлиным в 2002 г. в д. Юильск. Запись Г. Е. Солдатовой, Г. Б. Сыченко. Расшифровка, подстрочный перевод - Т. А. Молданов, уточненный перевод - А. А. Гриневич. Аудиозапись и рукопись хранятся в архиве сектора фольклора народов Сибири ИФЛ СО РАН.

4. Рукопись песни «Кунават миш нэ ар»- «Песня богини с [реки] Кунават». Исполнена С. Е. Тарлиным в 2002 г. в д. Юильск. Запись Г. Е. Солдатовой, Г. Б. Сыченко. Расшифровка, под-

\footnotetext{
${ }^{4}$ В «Поләм Төрәм ар» - «Песне Пелымского Торума», которая относится к жанру кайөәу ар, божество описано также, что может свидетельствовать об интерференции обрядовых песенных жанров. С другой стороны, это может быть свидетельством неоднозначного статуса Полума Торума - он и великое божество, чей образ во многом пересекается с верховным божеством Нуми Торумом, и отец медведя, что обуславливает исполнение песни в части обряда, посвященной медведю.
} 
строчный перевод - Т. А. Молданов, уточненный перевод - А. А. Гриневич. Аудиозапись и рукопись хранятся в архиве сектора фольклора народов Сибири ИФЛ СО РАН.

5. Рукопись песни «Йємәу Ас муви миши нэ ар» - «Песня богини Священной Оби». Исполнена С. Е. Тарлиным в 2002 г. в д. Юильск. Запись Г. Е. Солдатовой, Г. Б. Сыченко. Расшифровка, подстрочный перевод - Т. А. Молданов, уточненный перевод - А. А. Гриневич. Аудиозапись и рукопись хранятся в архиве сектора фольклора народов Сибири ИФЛ СО РАН.

6. Рукопись песни «Поләм йухан мищ нэ ар» - «Песня богини с реки Пелым». Исполнена С. Е. Тарлиным в 2002 г. в д. Юильск. Запись Г. Е. Солдатовой, Г. Б. Сыченко. Расшифровка, подстрочный перевод - Т. А. Молданов, уточненный перевод - А. А. Гриневич. Аудиозапись и рукопись хранятся в архиве сектора фольклора народов Сибири ИФЛ СО РАН.

7. Рукопись песни «Сөрәм ики ар» - «Песня господина с [реки] Сорум». Исполнена С. Е. Тарлиным в 2002 г. в д. Юильск. Запись Г. Е. Солдатовой, Г. Б. Сыченко. Расшифровка, подстрочный перевод - Т. А. Молданов, уточненный перевод - А. А. Гриневич. Аудиозапись и рукопись хранятся в архиве сектора фольклора народов Сибири ИФЛ СО РАН.

8. Рукопись песни «Хөрәу ики ар» - «Песня господина Херэна». Исполнена С. Е. Тарлиным в 2002 г. в д. Юильск. Запись Г. Е. Солдатовой, Г. Б. Сыченко. Расшифровка, подстрочный перевод Т. А. Молданов, уточненный перевод - А. А. Гриневич. Аудиозапись и рукопись хранятся в архиве сектора фольклора народов Сибири ИФЛ СО РАН.

9. Рукопись песни «Вєри вошәу ики миш ар» - «Песня удачи покровителя городка Вэри». Исполнена С. Е. Тарлиным в 2002 г. в д. Юильск. Запись Г. Е. Солдатовой, Г. Б. Сыченко. Расшифровка, подстрочный перевод - Т. А. Молданов, уточненный перевод - А. А. Гриневич. Аудиозапись и рукопись хранятся в архиве сектора фольклора народов Сибири ИФЛ СО РАН.

10. Рукопись песни «Мосәм ики ләсау лев» - «Песня слуги покровителя Назыма». Исполнена С. Е. Тарлиным в 2002 г. в д. Юильск. Запись Г. Е. Солдатовой, Г. Б. Сыченко. Расшифровка, подстрочный перевод - Т. А. Молданов, уточненный перевод - А. А. Гриневич. Аудиозапись и рукопись хранятся в архиве сектора фольклора народов Сибири ИФЛ СО РАН.

11. Рукопись песни «Јорен хулы сэвпи вөрт»-《Озерной рыбы [покровитель] с косами ворт [Хоймас]». Исполнена С. Е. Тарлиным в 2002 г. в д. Юильск. Запись Г. Е. Солдатовой, Г. Б. Сыченко. Расшифровка, подстрочный перевод - Т. А. Молданов, уточненный перевод - А. А. Гриневич. Аудиозапись и рукопись хранятся в архиве сектора фольклора народов Сибири ИФЛ СО РАН.

12. Рукопись песни «Йєм вош ики»- «Господин священного города». Исполнена С.Е. Тарлиным в 2002 г. в д. Юильск. Запись Г. Е. Солдатовой, Г. Б. Сыченко. Расшифровка, подстрочный перевод Т. А. Молданов, уточненный перевод - А. А. Гриневич. Аудиозапись и рукопись хранятся в архиве сектора фольклора народов Сибири ИФЛ СО РАН.

13. Рукопись песни «Тэк ики»- «Господин [села] Теги». Исполнена С. Е. Тарлиным в 2002 г. в д. Юильск. Запись Г. Е. Солдатовой, Г. Б. Сыченко. Расшифровка, подстрочный перевод Т. А. Молданов, уточненный перевод - А. А. Гриневич. Аудиозапись и рукопись хранятся в архиве сектора фольклора народов Сибири ИФЛ СО РАН.

14. Рукопись песни «Јэв кутәп ики»- «Господин середины Сосьвы». Исполнена С. Е. Тарлиным в 2002 г. в д. Юильск. Запись Г. Е. Солдатовой, Г. Б. Сыченко. Расшифровка, подстрочный перевод Т. А. Молданов, уточненный перевод - А. А. Гриневич. Аудиозапись и рукопись хранятся в архиве сектора фольклора народов Сибири ИФЛ СО РАН.

15. Рукопись песни «Пашит вөрт» - «Пашит ворт». Исполнена С. Е. Тарлиным в 2002 г. в д. Юильск. Запись Г. Е. Солдатовой, Г. Б. Сыченко. Расшифровка, подстрочный перевод Т. А. Молданов, уточненный перевод - А. А. Гриневич. Аудиозапись и рукопись хранятся в архиве сектора фольклора народов Сибири ИФЛ СО РАН.

16. Рукопись песни «Ай вөрт»- «Младший ворт». Исполнена П. И. Сенгеповым в 2002 г. в д. Юильск. Запись Г. Е. Солдатовой, Г. Б. Сыченко. Расшифровка, подстрочный перевод Т. А. Молданов, уточненный перевод - А. А. Гриневич. Аудиозапись и рукопись хранятся в архиве сектора фольклора народов Сибири ИФЛ СО РАН.

17. Рукопись песни «Ас тый ики» - «Верховьев Оби господин». Исполнена П. И. Сенгеповым, в 2002 г. в д. Юильск. Запись Г. Е. Солдатовой, Г. Б. Сыченко. Расшифровка, подстрочный перевод Т. А. Молданов, уточненный перевод - А. А. Гриневич. Аудиозапись и рукопись хранятся в архиве сектора фольклора народов Сибири ИФЛ СО РАН. 
Гриневич А. А. О структурной организаџии обрядовых песен медвежьего праздника казымских хантов...

\author{
A. A. Grinevich \\ Institute of Philology of the Siberian Branch of Russian Academy of Sciences, Novosibirsk, Russian Federation; \\ annazor@mail.ru
}

\title{
On the structural organization of ritual songs of the Kazym Khanty Bear Feast: songs of the gods luck mish ar and prayer-songs poekty ar
}

The article is devoted to the plot construction principles of ritual songs of the bear feast of Kazym Khanty. The ritual songs of a bear feast are characterized by multilevel text structure. In the field of view of the author are 8 mish songs (the songs of deity luck) and 7 poekty songs (prayers to a great gods). Comparing of mish songs the author distinguishes its two main types: male and female mish songs which are characterized by the following constant elements in the structure of the narrative: beginning; the description of the house of the deity; deity goes out of house; deity gets news from a crow; deity picks up; deity arrives to a bear feast; deity performs a dance that brings good luck in hunting. The number of constant motifs in poekty prayer songs is fewer: the description of the house in which the great deity sits; deity writes destinies; deity picks up; final: deity performs a dance that makes people's life better. Thereby the typicality of the mish and poekty songs is of different degrees. Male and female deities in mish songs have a large number of similarities. But the prayer-songs dedicated to great deities are more individual.

Keywords: ritual folklore, typical place, typical plot construction.

\section{References}

Grinevich A. A. Ustoychivye elementy poeticheskoy sistemy obryadovykh pesen medvezh'ego prazdnika kazymskikh khantov: poeticheskaya formula [Stable elements of the poetic system of ritual songs of the Kazym Khanty bear feast: poetic formula]. Sibirskiy filologicheskiy zhurnal [Siberian Journal of Philology]. 2016, no. 4, pp. 18-27. (in Russ.).

Grinevich A. A. O strukturnoy organizatsii obryadovykh pesen medvezh'ego prazdnika kazymskikh khantov [On the structural organization of kazym khanty ritual bear songs]. Sibirskiy filologicheskiy zhurnal [Siberian Journal of Philology]. 2018, no. 4, pp. 18-27. (in Russ.).

Kuz'mina E. N. O novykh aspektakh izucheniya proizvedeniy geroicheskogo eposa narodov Sibiri: opyt sistematizatsii «obshchikh mest» [On new aspects of the Siberian peoples heroic epos studying: the experience of “common places" systematization]. In: Pervyy Vserossiyskiy kongress fol'kloristov. Sbornik dokladov [The first allRussian Congress of folklorists. Collection of reports]. Moscow, 2006, vol. 3, pp. 55-69. (in Russ.).

Moldanov T. A. Posokh, primenyaemyy v medvezh'ikh igrishchakh. Rukopis' [Staff used in bear rituals. Manuscript]. Lichnyy arkhiv A. A. Grinevich [Personal archive of A. A. Grinevich].

Moldanova T. A. Znacheniya chastey tela v snovideniyakh khantov [The meaning of body parts in the Khanty dreams]. In: Narody Severo-Zapadnoy Sibiri [Peoples of North-Western Siberia]. Tomsk, Tomsk state University Publ. House, 2002, iss. 9, pp. 166-171. (in Russ.).

Toporov V. N. Eshche raz ob i.-e. *BUDH- (:BHEUDH-). Russkaya «Golubinaya Kniga» i iranskiy Bundahišn [Once again on i.-e. *BUDH- (:BHEUDH-). Russian "Pigeon book" and iranian Bundahišn]. In: Etimologiya. 1976 [Etymology. 1976]. Moscow, 1978, pp. 135-153. (in Russ.). 